\title{
Development of an Efficient Transformation System for Halotolerant Yeast Debaryomyces hansenii CBS767

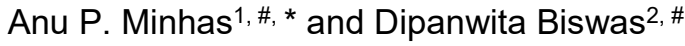

\author{
${ }^{1}$ University Institute of Engineering and Technology, Panjab University, Chandigarh, India; ${ }^{2}$ Universite \\ Grenoble Alpes, France \\ *For correspondence: annuminhas@gmail.com \\ \#Contributed equally to this work
}

[Abstract] Debaryomyces hansenii is one of the most osmotolerant and halotolerant yeasts. Further, its association with traditional cheese and meat products imparting special flavors to these products project this yeast with enormous biotechnological potential in the agrofood sector. However, lack of an efficient transformation system in $D$. hansenii still direct the complementation based assay in $S$. cerevisiae mutants for functional analysis of $D$. hansenii genes. Here, we have described the development of an efficient transformation system for $D$. hansenii that is based on a histidine auxotrophic recipient strain, DBH9 (generated by UV induced random mutagenesis), and the DhHIS4 gene as the selectable marker. Moreover, the same method has also been employed for gene disruption in $D$. hansenii by homologous recombination.

Keywords: Debaryomyces hansenii, Transformation, Gene disruption, Halotolerant yeast, Electroporation, Auxotroph

[Background] Debaryomyces hansenii CBS767 is one of the most osmotolerant and halotolerant yeasts and can tolerate salinity levels up to $4 \mathrm{M} \mathrm{NaCl}$, whereas growth of Saccharomyces cerevisiae is inhibited when salinity reaches above 1.7 M NaCl. Debaryomyces hansenii is frequently associated with traditional cheese and meat products imparting special flavors to these products. Therefore, this yeast is not only an excellent model to study salt tolerance mechanisms in eukaryotic cells but it also has enormous biotechnological potential in the agrofood sector. However, lack of efficient transformation system and gene disruption tools required for gene manipulation in $D$. hansenii is a big lacuna behind the molecular analysis of its halotolerant feature. Ricaurte and Govind (1999) developed an ura3 mutant based transformation system for $D$. hansenii; however this system exhibited low-efficiency. Despite the development of transformation system for Candida famata (Voronovsky et al., 2002), an anamorph of $D$. hansenii, functional studies of the genes from $D$. hansenii are still based on complementation of $S$. cerevisiae mutants. Our transformation system is based on a histidine auxotrophic strain, DBH9 and the DhHIS4 gene as the selectable marker. The same method has also been demonstrated for gene disruption in $D$. hansenii by homologous recombination (Minhas et al., 2009). 


\section{Materials and Reagents}

1. Pipettes (Thermo Fisher Scientific, catalog numbers: 4652080, 4652050, 4652020, 4652010)

2. Flask (Borosil, catalog numbers: 4980009, 4980012, 4980016, 4980021)

3. Graduated cylinder (Borosil, catalog number: 3021029 )

4. Centrifuge tube (Oak Ridge,catalog number: 541040)

5. Safe-Lock tubes $2.0 \mathrm{ml}$ (Eppendorf, catalog number: 0030120094)

6. Disposable Petri plates (Tarson, catalog number: 460090)

7. Pipette tips (Tarson, catalog numbers: $521000,521010,521020$ )

8. $0.2 \mu \mathrm{m}$ syringe filter (Millipore, catalog number: SLGP033RS)

9. $0.2 \mathrm{~cm}$ Electroporation cuvette (BioRad, catalog number: 1652086)

10. DBH9: D. hansenii strain CBS767 (MTCC 3461) $\Delta d h h i s 4$ (Original manuscript, Minhas et al., 2009)

11. Plasmid pDH4 (for cloning details refers to materials and methods section in Minhas et al., 2009)

12. Sodium phosphate, dibasic (Merck, catalog number: 567550 )

13. Sodium phosphate, monobasic (Merck, catalog number: 567549 )

14. DL-Dithiothreitol (DL- DTT) (Sigma, catalog number: 43815)

15. Glycerol (Sigma-Aldrich, catalog number:G9012)

16. Sucrose (Sigma, catalog number: S8501)

17. Glucose (Himedia, catalog number: MB037)

18. Agar (Himedia, catalog number: GRM026)

19. YPD broth (BD Difco, catalog number: DF0428-17-5)

20. Yeast minimal media-SD base (Clontech, catalog number: 630411)

21. Sterile water (Lab Pure-Series Model-Analytic UV)

22. YPD broth medium (see Recipes)

23. SD minimal agar medium with $0.3 \mathrm{M}$ sucrose (see Recipes)

24. YPD agar medium (see Recipes)

25. $1 \mathrm{M}$ sodium phosphate buffer, $\mathrm{pH} 7.5$ (see Recipes)

26. 1 M D L- DTT (see Recipes)

27. 1 M Sucrose (see Recipes)

\section{Equipments}

1. Incubator, New Brunswick ${ }^{\mathrm{TM}}$ Innova ${ }^{\circledR} 44$ (Eppendorf, model: M1282-0002)

2. UV-VIS spectrophotometer (Shimadzu, model: UV 1900)

3. Microcentrifuge (Eppendorf, model: 5415R)

4. Centrifuge (REMI, model: CPR-24Plus)

5. Water bath (Julabo, model: PURA 4)

6. Gene Pulser (BioRad, model: GenePulserXcell) 
7. Vortex (DLAB, model: MX-S)

8. Laminar air flow (Ocean life science corp, model: OLSC 113-4)

9. L- spreader (Himedia, model: PW1085)

10. Autoclave

\section{Software}

1. TBLASTN search tool on NCBI website (https://blast.ncbi.nlm.nih.gov/Blast.cgi?PROGRAM=tblastn\&PAGE TYPE=BlastSearch\&LINK LOC=blasthome)

\section{Procedure}

Notes:

a. Perform all steps involving microbial culture under sterilie environment in laminar air flow.

b. Use autoclaved water in all the steps.

1. Streak $\mathrm{DBH} 9$ strain on an YPD agar plate from frozen glycerol stock $\left(-70^{\circ} \mathrm{C}\right)$.

2. Incubate streaked plate at $25^{\circ} \mathrm{C}$ in an incubator for 3-4 days or till colonies appear. Note: Always start with freshly streaked culture for enhanced transformation efficiency.

3. Inoculate a single colony of DBH9 from the plate in $10 \mathrm{ml}$ YPD broth in a flask and incubate for appx. $24 \mathrm{~h}$ at $25^{\circ} \mathrm{C}$ at $200 \mathrm{rpm}$ for growth (saturated culture).

4. Check the absorbance of the culture (after 10 times dilution in water) using spectrophotometer at $600 \mathrm{~nm}$.

5. Re-inoculate $120 \mu \mathrm{l}$ of above grown saturated culture (if O.D. of culture is 3.0 ) into $30 \mathrm{ml}$ of YPD broth in a flask (so that an initial A600nm of 0.045 is acheived).

Note: The volume of re-inoculation may vary with O.D. of culture.

6. Grow the re-inoculated culture at $25^{\circ} \mathrm{C}$ at $200 \mathrm{rpm}$ for $\sim 16 \mathrm{~h}$ till the A600nm reached 2.6-2.8 (appx. $4.3 \times 10^{7}$ cells $\mathrm{ml}^{-1}$ ).

7. Confirm the absorbance using spectrophotometer.

Note: A drastic reduction in the number of transformants has been observed when the $A_{600 n m}$ of the harvested cells was $>2.8$.

8. Harvest cells from the liquid culture by centrifugation in a centrifuge at $4,500 \times g$ using centrifuge tube for $10 \mathrm{~min}$ at room temperature (RT).

9. Discard the flow-through.

10. Re-suspend cells pellet in $6 \mathrm{ml}$ of $50 \mathrm{mM}$ sodium phosphate buffer, $\mathrm{pH} 7.5$ (containing $25 \mathrm{mM}$ DL-Dithiothreitol).

Note: Vortex the cell suspension at low rpm for 5-10 s for re-suspension.

11. Incubate cells suspension in a $30^{\circ} \mathrm{C}$ water bath (pre-warm) for $15 \mathrm{~min}$. 
12. Again harvest cells from the suspension by centrifugation at $4,500 \times \mathrm{g}$ using centrifuge tube for 10 min at RT.

13. Discard the flow-through.

14. Wash the cells by re-suspending cell pellet in $15 \mathrm{ml}$ sterile water and harvest the cell pellet by centrifugation at $4,500 \times \mathrm{g}$ for $10 \mathrm{~min}$ at RT.

15. Discard the flow-through.

16. Repeat Steps 14-15.

17. Re-suspend the cell pellet in $1.0 \mathrm{ml}$ ice-cold $1 \mathrm{M}$ sucrose and transfer the entire chilled cell suspension to pre-chilled $2.0 \mathrm{ml}$ safe-lock tube.

18. Harvest the cell pellet again by centrifugation at $4,500 \mathrm{xg}$ for $10 \mathrm{~min}$ at $4{ }^{\circ} \mathrm{C}$ in a microcentrifuge.

19. Discard the flow-through.

20. Finally to the cell pellet, add $175 \mu$ ice-cold $1 \mathrm{M}$ sucrose to make the final volume of chilled cell suspension to $200 \mu$ in a safe-lock tube.

21. Uniformly re-suspend the cells by pipetting.

22. To this chilled cell suspension, add 0.25-1.5 $\mu$ gNA ( $\mathrm{pDH} 4$ plasmid) and transfer the entire mixture to $0.2 \mathrm{~cm}$ electroporation cuvette.

23. Electroporate the mixture using Gene Pulser at a setting of $2.3 \mathrm{kV}, 50 \mathrm{mFd}$ and $100 \Omega$. Note: Perform Steps 17-22 strictly on ice.

24. To the electroporation cuvette, immediately add $800 \mu \mathrm{l}$ of $1 \mathrm{M}$ sucrose solution (stored at room temperature).

25. Spread $200 \mu$ of the cells transformed with $\mathrm{pDH} 4$ on SD minimal medium (containing $0.3 \mathrm{M}$ sucrose) plates using L-spreader.

26. Incubate these plates at $25^{\circ} \mathrm{C}$ for 3-4 days for appearance of transformants positive for histidine prototrophy (as replicating vector $\mathrm{pDH} 4$ has DhHIS4 gene as the selection marker).

Note: We haven't used DhHIS4 as the selection marker in other yeast lines.

27. An extra sample is always used as a control where no DNA will be added.

28. Around 3,500 colonies would appear on the plate transformed with $0.25 \mu \mathrm{g}$ of pDH4 plasmid DNA. No colony will appear in control transformation without DNA.

\section{Data analysis}

For details, refers to Minhas et al. (2009).

\section{$\underline{\text { Recipes }}$}

1. YPD agar medium

a. Add $5.0 \mathrm{~g}$ of YPD broth powder in $250 \mathrm{ml}$ flask

b. Add $2.0 \mathrm{~g}$ of agar powder 
C. Dissolve the medium completely in $100 \mathrm{ml}$ sterile water and sterilize by autoclaving at 15 Ibs pressure $\left(121^{\circ} \mathrm{C}\right)$ for $15 \mathrm{~min}$

2. YPD broth medium

a. Suspend $5.0 \mathrm{~g}$ of YPD broth medium in $100 \mathrm{ml}$ distilled water in $250 \mathrm{ml}$ flask

b. Dissolve the medium completely and sterilize by autoclaving at $15 \mathrm{lbs}$ pressure $\left(121^{\circ} \mathrm{C}\right)$ for $15 \mathrm{~min}$

3. SD minimal agar media with $0.3 \mathrm{M}$ sucrose $(100 \mathrm{ml})$

a. Add $0.67 \mathrm{~g}$ Yeast minimal media-SD base to $80 \mathrm{ml}$ of distilled water in a $250 \mathrm{ml}$ flask

b. Add $2.0 \mathrm{~g}$ glucose, $2.0 \mathrm{~g}$ agar and $1.02 \mathrm{~g}$ sucrose to it

c. Mix the solution uniformly

d. Make up the final volume to $100 \mathrm{ml}$ with distilled water

4. $1 \mathrm{M}$ Sodium phosphate buffer, $\mathrm{pH} 7.5$

a. Add $20.209 \mathrm{~g}$ of sodium phosphate dibasic to $800 \mathrm{ml}$ of distilled water in a graduated cylinder ( $1000 \mathrm{ml}$ capacity) to prepare $0.0754 \mathrm{M}$ sodium phosphate dibasic solution

b. Add $3.394 \mathrm{~g}$ of sodium phosphate monobasic $(0.0246 \mathrm{M})$ to the above solution

c. Mix the solution uniformly and adjust the final $\mathrm{pH}$ to 7.5 using $\mathrm{HCl}$ or $\mathrm{NaOH}$ (if required)

d. Make up the final volume to $1 \mathrm{~L}$ with distilled water

5. $1 \mathrm{M} \mathrm{DL-DTT}$

Note: Always use freshly prepared DL-DTT solution.

a. Add $0.154 \mathrm{~g}$ of DL-DTT to $1.0 \mathrm{ml}$ of sterile $\mathrm{dH}_{2} \mathrm{O}$ in a safe lock tube

b. Dissolve completely by pipetting and sterilize the stock through a $0.2 \mu \mathrm{m}$ syringe filter

6. $1.0 \mathrm{M}$ Sucrose

a. Add $34.23 \mathrm{~g}$ of sucrose to $80 \mathrm{ml}$ of sterile $\mathrm{dH}_{2} \mathrm{O}$ in $250 \mathrm{ml}$ flask. Dissolve completely

b. Make up the final volume to $100 \mathrm{ml}$ and sterilize by autoclaving as directed above

\section{Acknowledgments}

The research was supported by Council of Scientific and Industrial Research, New Delhi, India. Special gratitude to Dr. Alok Mondal for guiding the original work and writing the published manuscript.

We would like to acknowledge our original publication "Minhas, A., Biswas, D. and Mondal, A. K. (2009). Development of host and vector for high-efficiency transformation and gene disruption in Debaryomyces hansenii. FEMS Yeast Res 9 (1): 95-102.

\section{Competing interests}

Authors have no competing interest. 


\section{References}

1. Minhas, A., Biswas, D. and Mondal, A. K. (2009). Development of host and vector for highefficiency transformation and gene disruption in Debaryomyces hansenii. FEMS Yeast Res 9 (1): 95-102.

2. Ricaurte, M. L. and Govind, N. S. (1999). Construction of plasmid vectors and transformation of the marine yeast Debaryomyces hansenii. Mar Biotechnol (NY) 1(1): 15-19.

3. Voronovsky, A. A., Abbas, C. A., Fayura, L. R., Kshanovska, B. V., Dmytruk, K. V., Sybirna, K. A. and Sibirny, A. A. (2002). Development of a transformation system for the flavinogenic yeast Candida famata. FEMS Yeast Res 2(3): 381-388. 